\title{
STUDENTS PERSPECTIVE ON ONLINE MEDICAL EDUCATION DURING LOCKDOWN AS A RESULT OF COVID-19 PANDEMIC
}

\author{
Muhammad Sajid Mehmooda, Wajahat Sultan Baigb, Sadia Azam Khanc, Fauzia Khan ${ }^{\text {, }}$, Shakil Ahmad \\ Awane, Ayesha Babar \\ associate Professor, Department of Physiology Quetta Institute of Medical Sciences, Quetta Cantt. \\ bSenior Registrar, Department of Medicine, Shifa Tamir-e-Millat University, Islamabad. \\ 'Assistant Professor, Department of Family Medicine/ Physician Rawalpindi Medical College. \\ ${ }^{\mathrm{d} A s s i s t a n t}$ Professor Department of Pathology, HITEC-IMS Taxila Cantt. \\ 'General Practitioner, Global Medical Solutions, UAE. \\ fProfessor, Department of Physiology, Muhammad College of Medicine.
}

\section{ABSTRACT:}

BACKGROUND \& OBJECTIVE: The COVID-19 pandemic has badly affected medical education. We explored the perspective of undergraduate medical students regarding e-learning across Pakistan.

METHODOLOGY: A questionnaire was developed and disseminated via what'sapp to MBBS students of medical institutes in Pakistan. The Google form data was retrieved in Microsoft Excel sheets and for further analysis. Ten medical colleges were selected based on a higher response rate. Out of 500 students, 492 students' replied with valid data. SPPS-version 22 was used for data analysis.

RESULTS: The mean age of respondents was $22 \pm 2.1 .64 .4 \%$ of respondents were female, and $43.6 \%$ were male. Only $5 \%$ of total students were of the opinion that online teaching was a good substitute for learning than face-to-face sessions. Majority of the students responded that online classes were not effective. There was no statistical difference between the support offered to students by faculty and college administration before and during COVID-19. About $43 \%$ of students responded that ZOOM software was a major platform for e-learning during the lockdown. Internet connectivity $(33 \%)$ was the major hurdle in e-learning, followed by distractions at home $(25 \%)$. Generally, health issues (35\%) and financial crises (25\%) in families were major stress factors.

CONCLUSION: The perspective of medical students regarding online teaching was not promising in our study. Most of the indicators were negative.

KEYWORDS: COVID-19, Medical education, E-learning, Students perception.

How to cite this:

doi: https://doi.org/10.37723/jumdc.v12i2.543

Mehmood MS, Baig WS, Khan SA, Khan F, Awan SA, Babar A. STUDENTS PERSPECTIVE ON ONLINE MEDICAL EDUCATION DURING LOCKDOWN AS A RESULT OF COVID-19 PANDEMIC. jumdc. $2021 ; 12(2): 111-118$.

doi: https://doi.org/10.37723/jumdc.v12i2.543

This is an Open Access article distributed under the terms of the Creative Commons Attribution License (http://creativecommons.org/licenses/by/4.0), which permits unrestricted use, distribution, and reproduction in any medium, provided the original work is properly cited. 


\section{INTRODUCTION:}

The COVID-19 pandemic has global implications, particularly on health and economies worldwide. All the disciplines of formal education have been affected. One of the great concerns is the peril of medical education. The lockdown during the pandemichas not only affected human life but also crumpled medical education and clinical trainingall over the world. With doctrines of social distancing, all face-to-face sessions were suspended due to the current COVID-19 pandemic ${ }^{[1]}$. The realization of the physicianspopulation ratio has never been as focused as it is now in the setting of a global emergency. The profound effects of COVID-19 may forever change how future physicians are educated. This pandemic presents practical and logistical challenges and concerns for patient safety, recognizing that students may potentially spread the virus while asymptomatic and may acquire the virus in the course of training ${ }^{[2]}$.

Education is the process of facilitating learning or the acquisition of knowledge, skills, values, beliefs, and habits. Due to the cancellation of face-to-face lectures and training, various teaching methodologies had been adopted ${ }^{[3]}$. For medical students in the clinical years of training, the COVID-19 pandemic had a greater impact on the day-to-day routine compared with the preclinical years. Faculty in medical colleges recognize the significance of attending face-toface lectures in the classroom where feedback and interaction are in person. They feel it is hard to be replicated in online classes. Standards will need to be set to ensure that online classes can equip students with the skills required for clinical clerkships.

The online environment will present a challenge to engage medical studentsin the true spirit of medicine which is based on direct interaction with patients and bedside learning ${ }^{[4]}$.

It is perceived that major pre-clinical teaching could be carried out with online or videoed lecture format, however, they do not substitute for inperson clinical training. As William Osler said, "Medicine is learned by the bedside and not in the classroom" ${ }^{[5]}$.During the clinical years, students join with multidisciplinary teams and drill their recently learned clinical skills under supervision, while getting enlightened with the working of the healthcare system. These important training periods help them in determining the future specialty as well, which suits them.

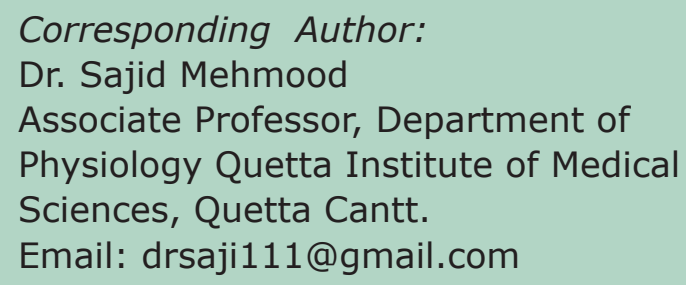

During the Covid pandemic, medical students have not been allowed to enter inpatient and outpatient departments in order to decrease viral transmission and to reduce the threat of acquiring the virus. Moreover, allowing students to attend the emergency and ward rounds will lead to a shortage of medical protective equipment. These are the guidelines endorsed by the American Association of Medical Colleges recommendation to take away medical students from direct patient interaction unless there is a critical healthcare workforce needed[6].However, there is another school of thought that discourages these recommendations, as they believe that it undermines medical professionalism and discourages future doctors to provide patient care $^{[7]}$.

Due to uncertainty of how long the pandemic will last, social distancing will continue to be observed, and current medical teaching is an area that needs special attention ${ }^{[8]}$.Only a few documented large-scale studies have been done to determine the experiences and perceptions of undergraduate medical students regarding online distance learning during lockdown ${ }^{[9]}$.There have been efforts going on for the last decade to transform the pedagogy of lecturing to recorded videos and animations for learning purposes. The simulated teaching strategies have been introduced. The lectures and dissection on cadaver have been replaced by learning on models and animated videos. Biotechnology has been introducing newer ways of learning in the medical profession ${ }^{[10]}$. However, these advanced teaching methodologies are in a trial phase and have not yet beenimplemented widely all over the globe, particularly in underdeveloped countries where the technical constraints and these modern costly devices are not available 
[11]. The acceptability of these newer methods by the students and teachers is also a big issue. However, during the pandemic online teaching and recorded videos became a necessity, but there was no preparedness for such modifications. The design and effectiveness of e-learning have not yet been clearly understood. A vast majority of senior teachers in the medical profession has not much knowledge of IT, and there was resistance to comply with computerbased online teaching methodologies. So, implementing active team-facilitated and selfdirected student-centered learning becomes a major issue in promoting individualized and inter-professional education ${ }^{[12]}$. In this study, the perceptions of undergraduate medical students regarding e-learning were explored belonging to various medical colleges of Pakistan across the board.

\section{METHODOLOGY:}

The study was conducted from 1st October to 30th October 2020. We had developed a questionnaire to assess the undergraduate students' perceptions of e-learning and the difficulties they faced during the pandemic. The questionnaire was uploaded in the Google form, and the online URL for the survey was disseminated to students of various medical colleges and universities in Pakistan across the board. The URL link was sent to students via email and What'sApp. The survey took approximately 2-3 minutes to complete. The study consisted of a "self-selected" convenience sample. The students' responses were recorded on google drive. The data was retrieved into Microsoft Excel spreadsheets. The sampling technique was non-probability purposive sampling. Equal no. of students from each professional was selected, so the sample was representative of the whole MBBS course. Out of 500 students selected, 492 students' replied with valid data. The percentages of the responses were calculated, and data were analyzed graphically. A self-administered questionnaire was developed, and students' responses regarding online learning were categorized. The scale was further characterized in to positive and negative response. Data were analyzed using IBM-SPSS version-22.

\section{RESULTS:}

The mean age of the study group was $22 \pm 2.1$ years. $66.4 \%$ of respondents were female, and the remaining $43.6 \%$ were male. During the last 6 months of lock-down from March to September 2020, the average daily hours utilized for study by the medical students in our sample was $3.5 \pm 1.6$ hours. The results of our study were not in favor of online teaching. Only $21.5 \%$ of total students were of the opinion that online teaching was a good substitute for lectures in the college, while $23.8 \%$ of students replied that they feel relaxed and fresh during online classes versus campus classes. Only $15.4 \%$ of the students replied that their concentration was better in online home classes versus campus classes, while only $16.2 \%$ of total students responded that their learning was better in online home classes. The $55.1 \%$ of students responded that their attendance was better in online classes than on campus. About $42.5 \%$ of students were of the opinion that faculty was more supportive during online classes; while $60.7 \%$ felt that their colleague students were more supportive during the lockdown than on-campus sessions. Different responses of students were analyzed.

There were five options for each question asked, and the mean score was three. Those scoring less than 3 were considered to have positive feedback regarding online learning, and those scoring more than three were categorized as having a negative perception of e-learning. Independent Student T-test for comparison of mean was applied to calculate the significance of positive and negative attitude of students regarding various parameters of e-learning. The statistical findings regarding students' perception of e-learning are represented in Table-I. It is evident from the statistical analysis that there was a significant difference between all the parameters studied. Hence, students' perception of online learning in terms of effectiveness, concentration, attendance, learning outcome, support from collegemates and faculty was significantly different during online classes in comparison with face-to-face on-campus sessions.

Only $24.1 \%$ of students could participate in their favorite sports, while $42.9 \%$ of students carried some exercise during the lockdown. Almost $45.6 \%$ of students gained weight during the lockdown. $67.4 \%$ of students offered the prayers 
regularly, and $50.5 \%$ of students developed new habits during the period of lockdown. Most of the time, among the five activities asked (Outdoor chores, book reading, net surfing, sleeping, and physical exercise) (53.5\%) was spent by students in internet surfing during the lockdown.43\% of students responded that ZOOM software was a major platform used for e-learning during lockdown (Figure-I). The second one enlisted was Google classroom (32\%).

The barriers faced by students during online classes are depicted graphically in Figure-II; major being internet connectivity reported by
$33 \%$ and second to that was distractions at home $(25 \%)$. The major problems faced by the students during the pandemic which adversely affected their lives are presented in Figure-III; amongst which health issues in the family were the most common (35\%) and second to that was a financial crisis (25\%). The students' opinions regarding the effectiveness of online classes compared to campus classes are displayed in Figure-IV. Only $5 \%$ of students were of the opinion that both are equally effective, while the major bulk responded that these were not effective (31\%).

Table-I: Students perspectives and attitudes towards E-learning

\begin{tabular}{|c|c|c|c|c|c|}
\hline $\begin{array}{l}\text { During online } \\
\text { classes vs. face } \\
\text { to face sessions }\end{array}$ & Responses & $\mathbf{N}$ & Mean & SD & $\begin{array}{l}\text { Independent T-test } \\
\text { for equality of means } \\
\text { (p-value) }\end{array}$ \\
\hline \multirow{2}{*}{$\begin{array}{l}\text { Fresh during } \\
\text { online classes }\end{array}$} & Positive & 156 & 1.6 & 0.46 & \multirow[t]{2}{*}{$<0.001$} \\
\hline & Negative & 336 & 3.6 & 0.59 & \\
\hline \multirow[t]{2}{*}{ Concentration } & Positive & 135 & 2.4 & 0.70 & \multirow[t]{2}{*}{$<0.001$} \\
\hline & Negative & 354 & 4.3 & 0.47 & \\
\hline \multirow[t]{2}{*}{ Learning } & Positive & 147 & 2.4 & 0.66 & \multirow[t]{2}{*}{$<0.001$} \\
\hline & Negative & 354 & 4.2 & 0.37 & \\
\hline \multirow{2}{*}{$\begin{array}{l}\text { Supported by } \\
\text { Fellow student }\end{array}$} & Positive & 290 & 1.5 & 0.51 & \multirow[t]{2}{*}{$<0.001$} \\
\hline & Negative & 192 & 4.5 & 0.50 & \\
\hline \multirow{2}{*}{$\begin{array}{l}\text { Supported by } \\
\text { faculty }\end{array}$} & Positive & 264 & 1.4 & 0.52 & \multirow[t]{2}{*}{$<0.001$} \\
\hline & Negative & 218 & 4.4 & 0.51 & \\
\hline \multirow{2}{*}{$\begin{array}{l}\text { Supported by } \\
\text { College admin }\end{array}$} & Positive & 237 & 1.47 & 0.52 & \multirow[t]{2}{*}{$<0.001$} \\
\hline & Negative & 244 & 4.57 & 0.49 & \\
\hline \multirow[b]{2}{*}{ Attendance } & Positive & 387 & 1.6 & 0.78 & \multirow[t]{2}{*}{$<0.001$} \\
\hline & Negative & 69 & 4.6 & 0.49 & \\
\hline \multirow[t]{2}{*}{ Effectiveness } & Positive & 63 & 2.6 & 0.52 & \multirow[t]{2}{*}{$<0.001$} \\
\hline & Negative & 414 & 4.7 & 0.44 & \\
\hline
\end{tabular}




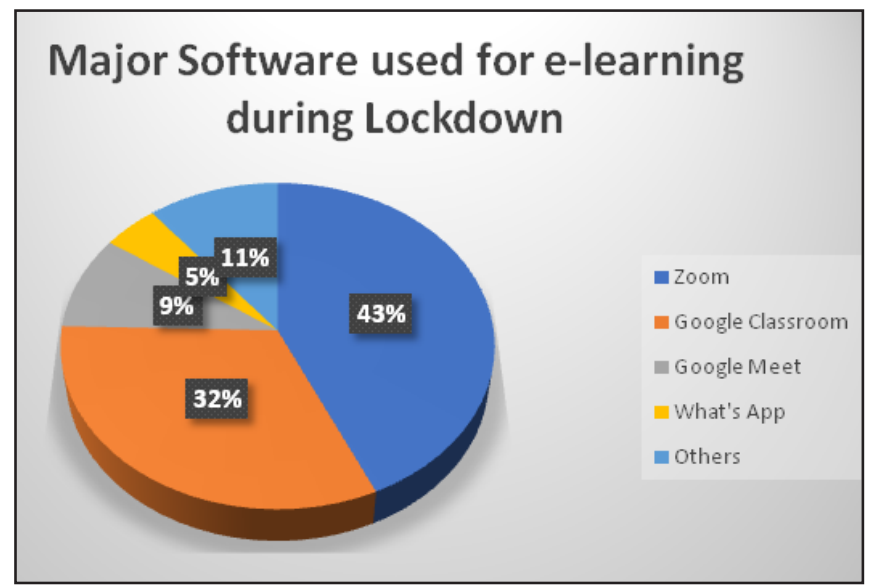

Figure-I:The software used by students/ institutions for e-learning during Lockdown which they were not using before COVID-19 Pandemic.

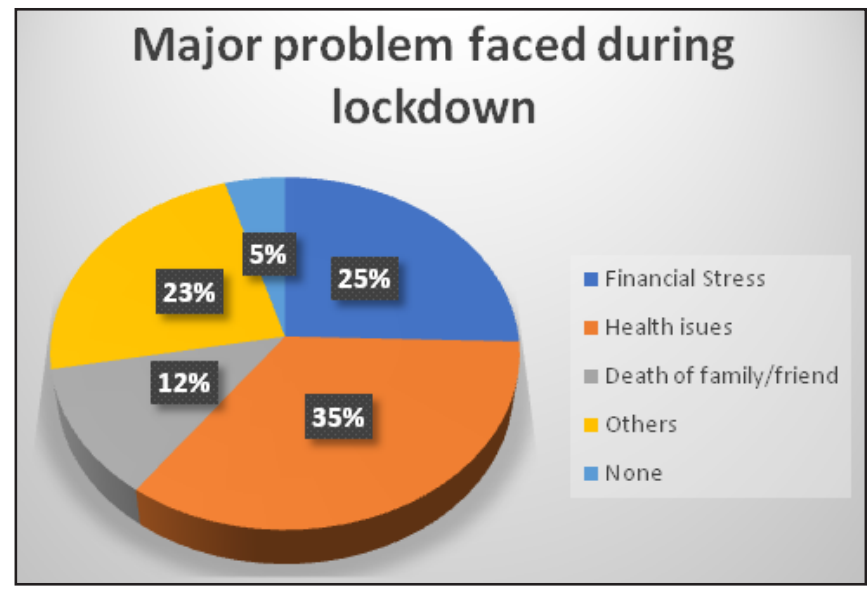

Figure-III: The response of students regarding the major problem faced by them during the lockdown in family.

\section{DISCUSSION:}

The study was conducted from $1^{\text {st }}$ October to 30th October 2020 to assess the student's perceptive on online teaching amongst the medical students of Pakistan. Pakistan is an under-developed country with scant facilities of internet and expertise of teachers for online teaching ${ }^{[13]}$.In Pakistan, there is no concept of distant learning in MBBS courses. Moreover, due to the sudden onset of the situation, the teachers were not trained for this emergency. Technologically, advanced countries have systems in place for e-learning and online medical education. This is not the case with most of the low-income countries like Pakistan ${ }^{[14]}$.

JUMDC Vol. 12, Issue 2, April-June, 2021

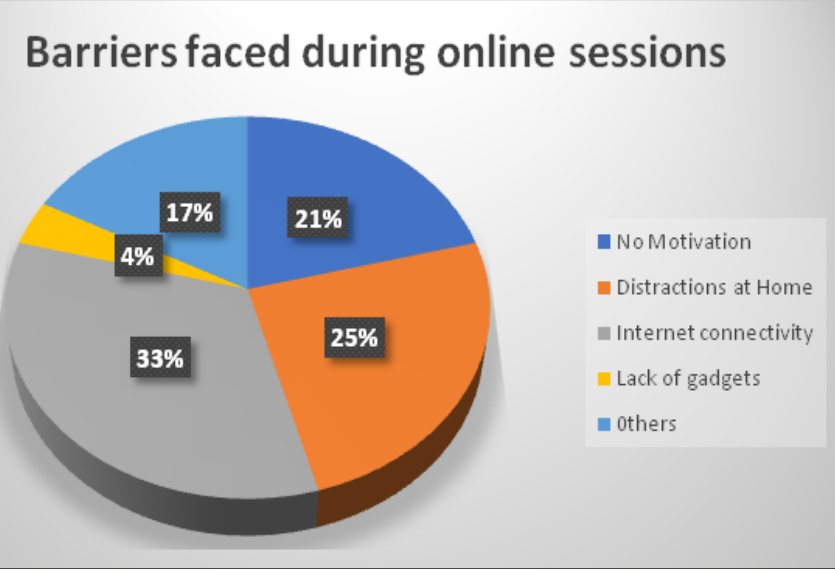

Figure-II: The major barriers faced by the students during online learning sessions at residence.

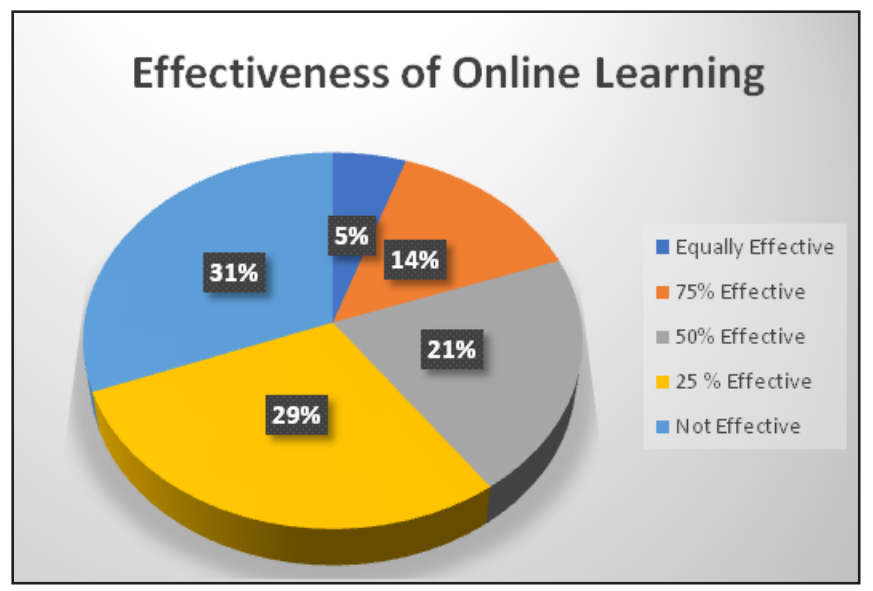

Figure-1V:Effectiveness of Online Learning in comparison to face to face in campus learning.

The average age of our study group was 22 years which is well within the range of 18 to 26 years of average age in Pakistani undergraduate medical students. There were more female student respondents in comparison to male students. The reason behind this fact is the more female students ratio in undergraduate medical institutes in Pakistan. In our study, $5 \%$ of students regarded online teaching to be a good substitute for lectures in college. The students' perceptions regarding concentration, alertness, and understating of the content delivered during online classes were dismal. There was a statistically significant difference amongst all the parameters explored in this study to determine students' perception of online-classes verses face to face 
on-campus sessions in terms of effectiveness, concentration, attendance, learning outcome, the support from school mates and the faculty. Our results were similar to the studyconducted by Abbasi $S$, et al.. ${ }^{[15]}$. There were also negative perceptions reported regarding online teaching among Chinese medical students ${ }^{[16]}$. The perceptions of students of medical schools even in developed countries like the United Kingdom, regarding online teaching were negative ${ }^{[17]}$.

The students' concentration, alertness, and reception of content during online classes were dismal. Our results were similar to the study conducted by Abbasi $S$ et al.[15]. There wasalso a negative perception regarding online teaching in Chinese medical students ${ }^{[16]}$. The perception of students of medical schools in developed countries like the United Kingdom regarding online teaching was even negative as wel|[17-18]. Our results vary from a study conducted by Anjali Verma in an Indian medical school in a sample of 130 students of 4 th year ${ }^{[18]}$. This variation in results may have been due to a smaller sample size and as only pre-clinical students were included in the study.

More than half of the students responded that their attendance was better during online classes than on-campus sessions. The results were similar to other studies conducted worldwide ${ }^{[17-19]}$. This result depicts that students benefited with their attendance as they did not have to travel to reach their institutes. Moreover, the attendance might have improved due to flexible timings during online classes. The results depict that students benefited in regard to their attendance because they did not have to travel in order to reach the institutes. Moreover, timings were flexible; hence the attendance was better during online classes. More than half of the students were of the opinion that they have lesser interaction with their teachers, though they had been in better touch with their fellows during the lockdown due to pandemics. Most of the students had a new experience and got familiarity with ZOOM software (used for synchronous learning) and then Google classroom (used mainly for asynchronous). ZOOM software got a lot of popularity for online conferencing. Our results were similar to other studies conducted during the pandemic ${ }^{[20]}$. The primary issue faced by our students was internet connectivity. Our results are similar to other studies conducted in Pakistan and other developing countries ${ }^{[14,21]}$. However major issue faced by the students in UK medical schools was family distractions ${ }^{[17]}$. Family distractions were the second biggest issue faced by students in our study group. Similar issues were reported in a study published in the Journal of Rawalpindi Medical College ${ }^{[22]}$.

The majority of students reported that online teaching was not effective in their opinion, while $29 \%$ of students reported that it was only $25 \%$ as effective in comparison to classroom learning. Only $5 \%$ reported it to be equally effective as face-to-face learning. This proportion was quite discouraging. It is incredibly challenging for these faculty members with no prior experience anda lack of training and IT support to engage in effective online medical teaching. Most of the faculty members in the institutions of Pakistan before the pandemic neither had any formal training for online education nor aware of the dynamics of live online interaction with the students. Moreover, there was resistance to accept and adapt to the newer teaching strategies. However, when we compared our results with other studies both in developed and developing countries, these were not much different. However, in other fields of education, the students ranked online teaching as a good alternative $^{[23]}$.

In general, health issues in the family followed by financial stress were the major issue faced by the students in our research group. More than $60 \%$ offered their prayers regularly, and about $40 \%$ of students gained weight during the pandemic. However, students across other countries reported depression and anxiety as major issues during the pandemic ${ }^{[24]}$. The difference may be to the socioeconomic status of our country and the greater ratio of praying and belief in God. When asked regarding the time spent during pandemic. More than half of the students responded that they spent most of their time in net surfing. Another interesting finding was that more than $40 \%$ developed new hobbies during the lockdown. Less than a quarter of students could participate in their favorite sports; however, more than $40 \%$ managed some physical activity. Our results are in line with other studies conducted ${ }^{[25-26]}$. 


\section{CONCLUSION:}

The perspectives of medical students regarding online teaching in our study were not in favor of online education. Most of the indicators were negative.

\section{RECOMMENDATIONS:}

Hence, to introduce online teaching strategies, systems would need to be developed, and intensive training and resources will be required to bring acceptability and effectiveness in online teaching to achieve the desired results. Moreover, a gradual introduction to online learning or a student-friendly, blended learning \& teaching approach would need to be adopted to suit our student population's needs.

\section{FUTURE PROSPECTS:}

- Comparative studies of students and teachers perception of synchronous and asynchronous learning strategies and blended learning using different platforms.

- Comparison of learning outcomes using different teaching approaches. Students' feedback regarding the continuation of online learning after the pandemic.

- Comparison of different indicators of learning outcomes pre and post COVD-19 era.

ACKNOWLEDGEMENT: None.

CONFLICT OF INTEREST: All authors disclose no conflict of interest.

$\begin{array}{llll}\text { GRANT } & \text { SUPPORT } & \& & \text { FINANCIAL } \\ \text { DISCLOSURE: None. } & & \end{array}$

\section{REFERENCES:}

1. Chick RC, Clifton GT, Peace KM, Propper BW, Hale DF, Alseidi $A A$, et al. Using technology to maintain the education of residents during the COVID-19 pandemic. Journal of Surgical Education: 2020; 77:729-732. Doi: 10.1016/j.jsurg.2020.03.018.

2. Rose S. Medical Student Education in the Time of COVID-19. Journal Pakistan Association A: 2020; 323(21):2131-2132 PMID: 32232420. Doi: $10.1001 /$ jama.2020.5227.

3. Scagnoli NI, Choo J, Tian J. Students' insights on the use of video lectures in online classes. British Journal of Educational Technology:
2019; 50:399-414. Doi: 10.1111/bjet.12572.

4. Hartman ND, Lefebvre CW, Manthey DE. A narrative review of the evidence supporting factors used by residency program directors to select applicants for interviews. Journal of Graduate Medical Education: 2019; 11:268273. Doi/10.4300/JGME-D-18-00979.3

5. Osler's W. Osler-isms to remember in your daily practice: Stanford medicine. [cited 2014 Nov 25]. Available from: https:// stanfordmedicine 25.stanford.edu/ blog/ archive/2014/10- Osler-isms-to-Rememberin-Your-Daily-Practice.html

6. Ahle S. COVID-19: the global disrupter of medical education. A SH Clinical News. 2020. Available from: https://www.ashclinicalnews. org/viewpoints/editors-corner/covid-19global-disrupter-medical-education/

7. Miller DG, Pierson L, Doernberg S. The Role of Medical Students During the COVID-19 Pandemic. Annals of Internal Medicine: 2020; 173:145-146. Doi: 10.7326/M20-1281.

8. Emanuel EJ. The inevitable reimagining of medical education. Journal of American MedicalAssociation. 2020; 323(12):11271128.

9. Chinelatto LA, Costa TR, Medeiros VM, Boog GH, Hojaij FC, Tempski PZ, et al. What You Gain and What You Lose in COVID-19: Perception of Medical Students on their Education. Clinics .2020; 75:e2133Doi:10.6061/clinics/2020/ e2133.

10. Nafrees AC, Roshan AM, Baanu AN, Nihma MF, Shibly FH. Awareness of Online Learning of Undergraduates during COVID 19 with special reference to South Eastern University of Sri Lanka. In Journal of Physics: Conference Series. 2020;712(1):012010. Doi: $10.1088 / 1742-6596 / 1712 / 1 / 012010$

11. Franchi T. The impact of the Covid-19 pandemic on current anatomy education and future careers: a student's perspective. Anatomical Sciences Education: 2020; (13):312-315. Doi: 10.1002/ase.1966.

12. Irby DM, Cooke M, O'Brien BC. Calls for reform of medical education by the Carnegie Foundation for the Advancement of Teaching: 1910 and $2010 . \quad$ Academic Medicine: 2010;85(2):220-227.

13. Iqbal T. Medical students' e-learning during Covid-19 lockdown. Pakistan Journal of 
Physiology: 2020;16(1):1-2.Available from: https://pjp.pps.org.pk/ index.php/PJP/ article/view/1240

14. Farooq F, Rathore FA, Mansoor SN. Challenges of Online Medical Education in Pakistan During COVID-19 Pandemic. Journal of College of Physicians and Surgeons of Pakistan: 2020; 30(Supp2): 67-69. Doi:10.29271/ jcpsp.2020.Supp. 2.S67.

15. Abbasi S, Ayoob T, Malik A, Memon SI. Perceptions of students regarding E-learning during Covid-19 at a private medical college.Pakistan Journal of Medical Sciences: 2020;36 (COVID19-S4):COVID19-S57-S61. Doi: 10.12669/pjms.36.COVID19-S4.2766।

16. Wang C, Xie A, Wang W, Wu H. Association between medical students' prior experiences and perceptions of formal online education developed in response to COVID-19: a crosssectional study in China. British Medical Journal Open. 2020; 10(10):e041886. Doi:10.1136/bmjopen-2020-041886

17. Dost S, Hossain A, Shehab M, Abdelwahed A, Al-Nusair L. Perceptions of medical students towards online teaching during the COVID-19 pandemic: a national crosssectional survey of 2721 UK medical students. BMJ Open: 2020; 10(11):e04237. Doi: $10.1136 /$ bmjopen-2020-042378

18. Verma A, Verma S, Garg P. Online Teaching During COVID-19: Perception of Medical Undergraduate Students. Indian Journal of Surgery:2020; 82(3):299-300.Doi: 10.1007/s12262-020-02487-2.

19. Chen E, Kaczmarek K, Ohyama H. Student perceptions of distance learning strategies during COVID-19. Journal of Dental Education: 2020; 1-2. Doi:/10.1002/jdd.12339

20. Srinivasan DK. Medical students' perceptions and an anatomy teacher's personal experience using an e-learning platform for tutorials during the Covid-19 crisis. Anatomical Sciences Education. 2020;13(3):318.319. Doi: 10.1002/asc.1970

21. Al-Balas M, Al-Balas HI, Jaber HM, Obeidat $\mathrm{K}$, Al-Balas $\mathrm{H}$, Aborajooh EA, et al. Distance learning in clinical medical education amid COVID-19 pandemic in Jordan: current situation, challenges, and perspectives. BMC Medical Education: 2020;20(1):341-347.
22. Noreen N, Umar M, Sabir S A, Farooq A. SWOC analysis of e-learning educational services at Rawalpindi Medical University in the midst of COVID-19.Journal of Rawalpindi Medical College:2020;24 Supple-1(2020):37-43.

23. Muthuprasad T, Aiswarya $S$, Aditya KS, Jha GK. Students' Perception and Preference for Online Education in India During COVID -19 Pandemic. Social Sciences and Humanities Open: 2021;3(1):100101. Available at SSRN: https://ssrn.com/abstract $=3596056$ or http://dx.doi.org/10.2139/ssrn.3596056

24. Nakhostin-Ansari A, Sherafati A, Aghajani F, Khonji MS, Aghajani R, Shahmansouri N. Depression and anxiety among Iranian Medical Students during COVID-19 pandemic. Iranian Journal of Psychiatry. 2020;15(3):228-235. Doi: 10.18502/ijps.v15i3.3815

25. Major S, Sawan L, Vognsen J, Jabre M. COVID-19 pandemicprompts the development of a Web-OSCE using Zoom teleconferencing to resume medical students' clinical skills training at Weill Cornell Medicine-Qatar. BMJ Simulation and Technology Enhanced Learning: 2020; 6:376-377. Doi: 10.1136/ bmjstel-2020-000629

26. Tariq S, Tariq S, Baig M, Alam SS. Adequacy of preventive measures, awareness, and attitude regarding the COVID-19 pandemic among university pharmacy students.2020;8:283-289. Doi: 10.46542/pe.2020.202.283289

\section{Author's Contribution:}

Muhammad Sajid Mehmood: Concept design, data collection, data analysis, and write-up. Wajahat Sultan Baig: Concept design, data collection, critical analysis.

Sadia Azam Khan: Correction \& revision.

Fauzia Khan: Data collection, critical analysis. Shakil Ahmad Awan: Data compilation, proof reading and critical analysis.

Ayesha Babar: Data collection, proof reading.

Submitted for Publication: 14-01-2021

Accepted after revision: 07-04-2021 